\title{
Impact of Social Media on Youth
}

\author{
P. Uma Rani, Padmalosani
}

\begin{abstract}
Social media contribute an online statement that attaches cluster of community, who network and share the information. There are well known social media like Facebook, Wikipedia, twitter, Google+, Pinterest, LinkedIn, Instagram, Tumblr and reddita. They are all social networking websites where users can share their information to the public. Business people also can promote their products through social media and get crowd funding. Social media analytics collects and analyze the data from blogs and social media website that helps business people to frame a wise decision. Social media also influence students positively to understand human behaviours and negatively become selfish and fanatic. Thus social media is used both for construction and destruction purpose for people from different walks of life.
\end{abstract}

KEYWORDS: Social media, human behaviour, construction and destruction purpose

\section{INTRODUCTION}

The study concentrates on the impact of social media towards youth. Technology is considered as the king and human must be knowledgeable to control the king. It is essential to educate youth regarding the usage of social media to upgrade in their career and personal development. Technology has succeeded by going inside our body, and human blood and emotions.

\section{REVIEW OF LITERATURE}

Nia Crawford, Loebig in their research on "How Does Social Media Effect Youth?" (2015) stated that social media like a coin have valuable and harmful impact on the youth. It helps youngsters to flourish and grab downward, hence youth has to be careful. Youth connect with many people and promote themselves in their career. Social media helps youngsters to share their opinions with others.

\section{OBJECTIVES}

To understand the purpose of using social media

To study the influence of social media towards youngsters

To offer suggestions to youth to use social media in the right way

\section{METHODOLOGY}

Survey method used to collect data from respondents belonging to the age group of 20-25 years. Questionnaires constructed and distributed to 150 respondents. Convenience sampling method used, when selecting the respondents. Chi square and regression tools used to analyze the collected

Revised Manuscript Received on September 10, 2019.

Dr. P. Uma Rani - Professor \& Head-DoMS. Saveetha Engineering College, Chennai-602105, Tamil Nadu, India.

(Email: umarani@saveetha.ac.in)

Ms.Padmalosani, Faculty,Accounting \& Finance - Business studies, Ibra College of Technology, Ibra, Al-Sharqiyah Region, Sultanate of Oman.

(Email: d.padmalosani@gmail.com) data. Secondary data collected from journals, books and websites

\section{PURPOSE OF USING SOCIAL MEDIA}

Majority of the youth are shifting from Television media to social media as it has influenced them. Social media influences youngster's life styles and it is helping them to create a network throughout the world. Social media makes it effortless to make relationship with anyone by expressing their likes and dislikes, which can be easily done. They are able to connect with every one through texting, sharing pictures and videos to their friends and the information can be passed on immediately at cheaper cost. Social networking offers a platform to discuss some burning current issues. Social media is a channel through which they are able to share their thoughts and feelings with their peers. As the youth get older they are in dilemma as what can be done, they get guidelines for the problems in their life. Help students to share information regarding the assignments to be submitted. Ticket booking for a movie show, a hotel and flight and train tickets for local as well as for an overseas travel trip can be done immediately. Social media has facilitated political change as the youth are more aware of politics.

\section{INFLUENCE OF SOCIAL MEDIA TOWARDS YOUTH}

Social media encourages unethical videos, chatting, images that generate difference of opinion among them. Such postings are weakening the affiliation between nations. As the youth are immature they fall victim to the cyber bullying. This affects the mental and emotional health of the youth and leads to suicide. As there is lack of privacy in social media site there are chances of misusing the private information by a third party. Due to use of social networking face to face interaction is getting reduced. It spreads false rumors and unreliable information. Criminals use social media to commit crimes. It supports amateur medical advice which is critical and life-threatening.

\section{ANALYSIS \& RESULTS}

HO:

There is no association on time spent in networking and the act of youth

H1:

There is association on time spent in networking and the act of youth

Positive -51, Negative -99

Published By

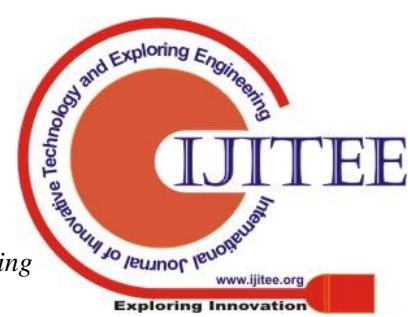




\begin{tabular}{|l|l|l|l|l|}
\hline S,No & $\begin{array}{l}\text { Average Time } \\
\text { Spent }\end{array}$ & \multicolumn{3}{|l|}{ Impact on performance } \\
\cline { 3 - 5 } & YES & NO & TOTAL \\
\hline 1 & 1hr & 9 & 12 & 21 \\
\hline 2 & 3 hours & 14 & 31 & 45 \\
\hline 3 & $\begin{array}{l}\text { More than } 3 \\
\text { hours }\end{array}$ & 28 & 56 & 84 \\
\hline & TOTAL & 51 & 99 & 150 \\
\hline
\end{tabular}

\section{Inference:}

The Tabulated values $\psi^{2} \alpha=0.05$ for 2 differences is 5.99. The calculated value is 28.9 , more than the table value, $\mathrm{H} 1$ accepted and $\mathrm{H}_{0}$ is rejected. There is association on time spent in networking and the act of youth.

HO:

There is no association on networking and lack of critical thinking skills

H1:

There is an association on networking and lack of critical thinking skills

\begin{tabular}{|c|c|c|c|c|}
\hline \multirow[t]{2}{*}{ S No } & \multirow[t]{2}{*}{ Social media } & \multicolumn{3}{|c|}{ Impact on critical thinking } \\
\hline & & YES & NO & TOTAL \\
\hline 1 & Whats App & 13 & 46 & 21 \\
\hline 2 & Face Book & 26 & 35 & 45 \\
\hline 3 & Instagram & 7 & 23 & 84 \\
\hline Total & & 46 & 104 & 150 \\
\hline
\end{tabular}

Positive - 97 / Negative - 53

Inference: The Tabulated values $\psi^{2} \alpha=0.05$ for 2 differences is 5.99 . The calculated value is 12.8 , more than the table value, $\mathrm{H}_{1}$ accepted and $\mathrm{H}_{0}$ is rejected. There is association on networking and lack of critical thinking skills.

\section{FINDINGS}

- $\quad$ The present youth are wasting much of their time in social media instead of some productive purposes

- It is understood from chi square test, there is association on time spent in networking and the act of youth

- They are moved away from their career and personal development.

- $\quad$ Youth are addicted to social media by sharing pictures and chatting unnecessarily

- $\quad$ As parents are busy with their day to day activities, they are unable to spare their time with their kids. Social media helps the present youth to get rid off from their boredom

- $\quad$ Faulty religious information's on social media will spoil the countries integrity by influencing the youth.

- $\quad$ Youth are our future pillar of our nation. They believe the words tweeted by the politicians and get spoiled

- Some of the information shared in social media helps to upgrade the knowledge of the youth

- Networking through social media helps for the career up liftment of the youth.

- There is an association on networking and lack of critical thinking skills

- Internets helps youth to learn the social values in life.
- $\quad$ Social media helps to expand social skills, gain lot of friends.

- Youngsters do cyber bully which leads to depression and suicidal thoughts of the affected party

\section{SUGGESTIONS}

- $\quad$ Youth must be taught to analyze the data and able to judge the information that contaminates our values which will certainly benefit our country, the companies with a sense of greatness in life.

- $\quad$ Young people should not provide their personal information in social media as it will be misused by third parties.

- Minimize negative effects of social media while chatting

- $\quad$ To safe guard the future generation, teachers and parents should make sure what the children are doing in social media

\section{CONCLUSION}

This study was mainly conducted to check the impact of networking on youngsters. It is understood that they are wasting the precious time and also leads to health problems due to sleepless nights. When posting information in social media cultural and religious values must be kept in mind and should not affect anyone.

\section{REFERENCE}

1. Beres, D.: 5 Weird Negative Effects of Social Media on Your Brain. Reader's Digest.

2. Jamal J. Al-Menayes, Department of Mass Communication, Kuwait University, Kuwait. International Journal of Psychological Studies, Vol. 7, No. $4 ; 2015$

3. Lusk, B. (2010). Digital natives and social media behaviors: An overview. The Prevention Researcher 17(5), 3-6.

4. S. Mittal, A. Goel, R. Jain, "Sentiment analysis of Ecommerce and social networking sites," in

5. www.researchgate.net - Impact of Social Networking on Indian Youth 